Atmos. Chem. Phys., 6, 4345-4359, 2006

www.atmos-chem-phys.net/6/4345/2006/

(c) Author(s) 2006. This work is licensed

under a Creative Commons License.

\title{
Modelling soil dust aerosol in the Bodélé depression during the BoDEx campaign
}

\author{
I. Tegen ${ }^{1}$, B. Heinold ${ }^{1}$, M. Todd ${ }^{2}$, J. Helmert ${ }^{1}$, R. Washington ${ }^{3}$, and O. Dubovik ${ }^{4}$,* \\ ${ }^{1}$ Leibniz Institute for Tropospheric Research, Leipzig, Germany \\ ${ }^{2}$ Department of Geography, University College London, UK \\ ${ }^{3}$ Oxford University Centre for the Environment, University of Oxford, UK \\ ${ }^{4}$ NASA Goddard Space Flight Center, Greenbelt, MD, USA \\ *now at: Laboratoire d'Optique Atmosphérique, University of Lille, France
}

Received: 7 March 2006 - Published in Atmos. Chem. Phys. Discuss.: 25 May 2006

Revised: 24 August 2006 - Accepted: 20 September 2006 - Published: 27 September 2006

\begin{abstract}
We present regional model simulations of the dust emission events during the Bodélé Dust Experiment (BoDEx) that was carried out in February and March 2005 in Chad. A box model version of the dust emission model is used to test different input parameters for the emission model, and to compare the dust emissions computed with observed wind speeds to those calculated with wind speeds from the regional model simulation. While field observations indicate that dust production occurs via self-abrasion of saltating diatomite flakes in the Bodélé, the emission model based on the assumption of dust production by saltation and using observed surface wind speeds as input parameters reproduces observed dust optical thicknesses well. Although the peak wind speeds in the regional model underestimate the highest wind speeds occurring on 10-12 March 2005, the spatio-temporal evolution of the dust cloud can be reasonably well reproduced by this model. Dust aerosol interacts with solar and thermal radiation in the regional model; it is responsible for a decrease in maximum daytime temperatures by about $5 \mathrm{~K}$ at the beginning the dust storm on 10 March 2005. This direct radiative effect of dust aerosol accounts for about half of the measured temperature decrease compared to conditions on 8 March. Results from a global dust model suggest that the dust from the Bodélé is an important contributor to dust crossing the African Savannah region towards the Gulf of Guinea and the equatorial Atlantic, where it can contribute up to $40 \%$ to the dust optical thickness.
\end{abstract}

\section{Introduction}

Wind-blown dust emitted from soil surfaces in arid and semiarid regions contributes significantly to the global aerosol optical thickness (IPCC, 2001), and dust plumes emerging from

Correspondence to: I. Tegen

(itegen@tropos.de) continents are prominent features in satellite retrievals of atmospheric particles. The dust aerosol particles scatter and partly absorb solar radiation, and, due to their relatively large particle sizes of typically $2 \mu \mathrm{m}$ for far-travelled dust (larger particle sizes are found near dust source regions) they have the potential to change outgoing terrestrial radiation fluxes ("greenhouse effect") (Lacis and Mishchenko, 1995). The magnitude and even the sign of dust radiative forcing remains uncertain (IPCC, 2001). While in the global annual mean the radiative forcing by dust at the top-of-atmosphere (TOA) is estimated to range from -1.4 to $1 \mathrm{~W} \mathrm{~m}^{-2}$ (Mhyre and Stordahl, 2001; Perlwitz et al., 2001), dust events can locally cause radiative forcing over oceans in the solar spectrum as high as $-130 \mathrm{~W} \mathrm{~m}^{-2}$ (Haywood et al., 2003). In contrast, Haywood et al. (2005) recently estimated a longwave radiative effect of up to $+50 \mathrm{~W} \mathrm{~m}^{-2}$ in cloud-free regions of the Sahara. The presence of atmospheric dust reduces surface temperatures and changes atmospheric heating rates as well as the hydrological cycle (e.g., Miller et al., 2004). Dust may influence cloud properties (e.g., Wurzler et al., 2000), the formation of ice clouds (e.g., Ansmann et al, 2005), atmospheric chemistry via heterogeneous surface reactions (e.g., Dentener et al., 1996; Bonasoni et al., 2004), and nutrient delivery to marine (e.g. Martin, 1990; Jickells et al., 2005) and terrestrial ecosystems (Chadwick et al., 1999; Okin et al., 2004). Estimates of global soil dust emissions range from 1000 to $3000 \mathrm{Mt} \mathrm{year}^{-1}$ (IPCC, 2001). The largest sources of dust are located in North Africa; about $50-70 \%$ of global dust emissions are estimated to originate from the Saharan desert (Goudie and Middleton, 2001; Mahowald et al., 2005). Observational evidence indicates a considerable increase in dust emissions from the Sahara in past decades (N'Tschayi Mbourou et al., 1997; Prospero and Lamb, 2003).

Not all desert surfaces are effective sources of dust aerosol. Analyses of multi-year satellite retrievals of the Absorbing Aerosol Index from the Total Ozone Mapping Spectrometer (TOMS AAI; Herman et al., 1997) reveal that enclosed

Published by Copernicus GmbH on behalf of the European Geosciences Union. 


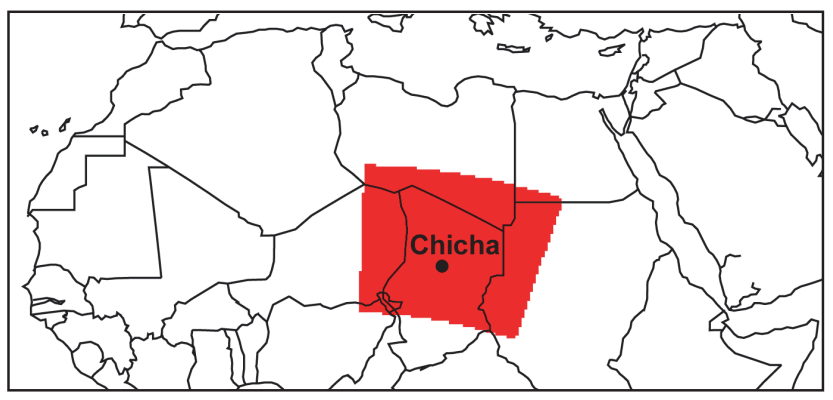

Fig. 1. Location of the field site "Chicha" in the Bodélé depression, Chad. The domain of the regional model is indicated in red.

topographic depressions can be particularly active sources of dust, so-called "hot-spots" of dust emission (Ginoux et al, 2001; Prospero et al., 2002; Washington et al., 2003). These areas may have contained lakes during past wetter climate periods, or can be end-points for riverine sediment transport. Such conditions can have led to accumulation of fine-grained sediments that are easily deflated by winds. The Bodélé depression, which lies between the Tibesti Mountains and Lake Chad, is the most active dust source in the Sahara desert (Prospero et al., 2002; Washington et al., 2003); at this location the presence of dust is detected throughout the year, although a pronounced seasonal cycle is evident with peak emission in winter/spring (Washington and Todd, 2005; Washington et al., 2006). That the Bodélé depression is such a dominant dust source is due to the coincidence of an extensive source of diatomite sediment, which is the source of the major dust plumes emerging from the region, and high velocity winds associated with the Bodélé Low Level Jet (Washington and Todd, 2005; Washington et al., 2006; Todd et al., 2006).

Dust emissions cannot be measured directly at large scales, therefore estimates of dust aerosol distribution and its effects are generally based on model calculations that use the best available information on soil properties and meteorology to simulate dust fluxes. Most global dust models prescribe enclosed topographic depressions as preferential sources for dust aerosol emission (e.g., Ginoux et al., 2001; Tegen et al., 2002; Zender et al., 2003), but lack of information about soil and particle properties in these regions, which are often difficult to access, lead to large uncertainties in the computation of dust emission fluxes. In particular, for the remotely situated Bodélé depression few data exist that can be used as input for dust emission models. In February and March 2005 a group of international scientists carried out a field study in the Bodélé depression (Bodélé Dust Experiment, BoDEx) (Giles, 2005; Washington et al., 2006; Todd et al., 2006) aiming at improved knowledge about particle properties and the understanding of dust emission processes in this important dust source region. The BoDEx campaign field site "Chicha" was located at $16^{\circ} 53^{\prime \prime} \mathrm{N}, 18^{\circ} 33^{\prime \prime} \mathrm{E}$, at the eastern border of massive diatomite deposits (Fig. 1). These deposits had formed at the bottom of paleo-lake Chad, and are suspected to be very effective sources for the dust plumes that are characteristic of the region. First findings from this field study include the recognition of the importance the Bodélé lowlevel jet as the cause for dust deflation during north Hemisphere winter in this region (Washington et al., 2006). Sunphotometer measurements during the field experiment show that dust produced in the Bodélé is highly reflective at solar wavelengths (Todd et al., 2006). This finding is in agreement with recent retrievals of relatively high single scattering albedos of Saharan dust at various sites (Dubovik et al., 2002a). From field observations Todd et al. (2006) suggest the dust emission from the area of diatomite sediment, which covers an area of $10800 \mathrm{~km}^{2}$ to be $1.2 \pm 0.5 \mathrm{Tg} \mathrm{day}^{-1}$ during substantial dust plume events.

Here we present results of dust models constrained by observations from the BoDEx field experiment. The aim of this study is (i) to test the applicability of the physical description of the emission parameterization when comparing the results to optical thickness measurements taken directly in the active source area, and (ii) determine the importance of the radiative forcing by atmospheric dust load for the surface temperature changes measured at the field site during a major dust event.

\section{Observations during BoDEx}

Compilations of lake status data (e.g., Damnati et al., 2000), and recent analysis of remotely-sensed surface data (Schuster et al., 2005) confirm that during the middle Holocene ca. 6000 years before present in the Bodélé depression, centred near $17^{\circ} \mathrm{N}, 18^{\circ} \mathrm{E}$, the paleo-lake Mega-Chad covered a surface area five times larger compared to conditions at the late Holocene (Coe, 1998). Substantial layers of diatomite sediment formed from the shells of freshwater diatoms in the deepest part of this paleo-lake, which now covers an area of ca. $10800 \mathrm{~km}$ (see Fig. 6) and forms a highly productive desert dust source, seemingly the most active in the world. Diatomite is a porous sediment consisting of ca. $90 \%$ silicon dioxide, with bulk densities that can be as low as $1 \mathrm{~g} \mathrm{~cm}^{-3}$. At the BoDEx site the density of diatomite samples was determined as $2.1 \mathrm{~g} \mathrm{~cm}^{-3}$ (Todd et al, 2006), determined as bulk density of surface samples using non-solvent chloroform as a suspension fluid.

The BoDEx multidisciplinary field experiment took place from 28 February to 13 March 2005. The observation site "Chicha" is located at $16^{\circ} 53^{\prime} \mathrm{N}, 18^{\circ} 33^{\prime} \mathrm{E}$ in $179 \mathrm{~m}$ altitude at the eastern margin of the large diatomite deposit originating from the paleo-lake Mega-Chad. Surface measurements of meteorological parameters at $2 \mathrm{~m}$ height during BoDEx included temperature, wind speed, humidity, solar and UV radiation and air pressure (Washington et al., 2006). Aerosol optical properties were measured during the field experiment using a Cimel C-318 sun-sky spectral radiometer of the type 
used in the Aerosol Robotic Network (AERONET: Holben et al., 1998), measuring sun and sky radiances at wavelengths of $440,670,870$, and $1020 \mathrm{~nm}$. The retrieval algorithm (Dubovik et al., 2006) is a revised version of the standard AERONET retrieval technique (Dubovik and King, 2000). The algorithm inverts measurements of aerosol optical thickness and diffuse sky radiation and derives aerosol particle size distribution in the range from 0.05 and $15 \mu \mathrm{m}$ (radius) and the complex refractive index at the 4 wavelengths. The new retrieval scheme assumes the aerosols as a mixture of spherical and non-spherical aerosol components, and the fraction of aerosol non-sphericity is derived as an additional retrieval parameter. The mixture of randomly oriented spheroids is used for modelling optical properties of the non-spherical aerosol component. The spheroid mix (aspect ratio distribution) is refined (compare to earlier studies by Dubovik et al., 2002b) from analysis of detailed polarimetric properties of desert dust sample measured in the laboratory (Volten et al. 2001). In addition, Dubovik et al. (2006) included additional minor constraints for limiting the concentrations of fine particles with radii $0.05 \mu \mathrm{m}$. Surface albedos were assumed based on surface reflectance climatologies derived from satellite observations (Moody et al., 2005). Additional optical thickness measurements were taken by handheld Microtops sun photometers, measuring aerosol optical thicknesses (AOTs) every $30 \mathrm{~min}$ at the wavelength of 440 , 675,870 and $1020 \mathrm{~nm}$. Todd et al. (2006) show that the AOT retrievals by the different instruments agree well with each other during times when both instruments were operating, therefore the Microtops instrument could be used to fill gaps in the observational AOT record when the Cimel instrument was not operating (notably during severe dust emission events).

During the field expedition, individual dust events were observed on the days 28 February, 4 March and 9 March, while a major dust storm occurred on 10-12 March (Washington et al., 2006). During the dust storm, when peak 2$\mathrm{m}$ wind speeds reached $16 \mathrm{~m} \mathrm{~s}^{-1}$, dust production reportedly occurred by a "self-abrasion" process of saltating diatomite flakes, which partly disintegrate when colliding mid-air or on impact with the ground (Giles, 2005). At this location fine dust particles are apparently produced by disintegration of the saltators themselves, and not by dislocation of small particles from soil aggregates at the soil surface through the impact of saltating sand grains, as described e.g. in $\mathrm{Lu}$ and Shao (1999). Dust production at the field site occurred when the surface wind speed exceeded $10 \mathrm{~m} \mathrm{~s}^{-1}$ (Todd et al., 2006), which is a higher threshold value compared to the often observed value of dust production starting at surface wind speeds exceeding 6-7 $\mathrm{m} \mathrm{s}^{-1}$ (e.g., Gillette, 1978).

\section{Model description}

\subsection{Dust emission}

Size-resolved dust emission fluxes for the BoDEx location and time period of the field study are computed using the model described in Tegen et al. (2002), which is based on the emission scheme developed by Marticorena et al. (1997). Dust emission is initiated by saltating soil particles, which produce smaller dust particles that can be transported over large distances.

The model computes dust emission fluxes $F$ in nonvegetated areas depending on surface wind friction velocities, surface roughness, soil particle size distribution, soil moisture, and snow cover, as

$$
\begin{array}{r}
F=\alpha \frac{\rho_{a}}{g} u_{*}^{3} \sum_{i}\left[\left(1+\frac{u_{* t r_{i}}}{u_{*}}\right)\left(1-\frac{u_{* t r_{i}}^{2}}{u_{*}^{2}}\right) s_{i}\right] \\
\left(1-A_{\text {veg }}\right)\left(1-A_{\text {snow }}\right)
\end{array}
$$

where $\alpha$ is the ratio between dust flux and horizontal saltation flux, $\rho_{a}$ is the air density, $g$ is the gravitational constant, $u_{*}$ is the surface friction velocity, $u_{* t r}$ is the threshold friction velocity for size fraction $i, s_{i}$ is the relative surface area covered by particles of size fraction $i, A_{\mathrm{veg}}$ is the part of the area covered by vegetation, and $A_{\text {snow }}$ is the part of the area covered by snow.

Soil particle size distributions were derived from soil texture data (Zobler, 1986), assuming each texture class to be a composite of four particle size modes (clay, silt, fine sand, coarse sand). These size classes are assumed to be lognormally distributed with mode diameters at $2 \mu \mathrm{m}, 15 \mu \mathrm{m}$, $158 \mu \mathrm{m}$ and $720 \mu \mathrm{m}$ (Tegen et al., 2002). Enclosed topographic depressions including the Bodélé were treated as preferential "hot-spot" source areas, and the soils in these areas were initially specified to consist of uniformly textured particles with mode diameters of $15 \mu \mathrm{m}$, which disaggregate into $2 \mu \mathrm{m}$ dust particles during saltation events. Surface wind friction velocities are computed from surface wind speeds and surface roughness data, assuming neutral stability conditions

$u_{*}=u(z) \frac{\kappa}{\ln \left(z / z_{0}\right)}$,

where $u$ is the surface wind speed at reference height $z$, $\kappa$ is the von Karman constant and $z_{0}$ is the aerodynamic roughness length. The threshold friction velocities for initiation of dust emission are computed depending on soil particle size distribution following Marticorena and Bergametti (1995), but assuming constant surface roughness within each model gridcell. The ratios between the vertical dust and horizontal saltation fluxes also depend on the soil texture, and range from $\alpha=10^{-7} \mathrm{~cm}^{-1}$ for coarse sand or clay soils, to $\alpha=10^{-5} \mathrm{~cm}^{-1}$ in gridcells containing "hot spot" sources (Tegen et al., 2002). Thus the size distribution of the mobilized dust depends on both the surface properties and the surface wind speed. 
The dust emission model has already been used with a global offline transport model (Tegen et al., 2004); and coupled on-line with the global climate model ECHAM5 (Stier et al., 2005).

\subsection{Box model}

While dust emissions and transport during the BoDEx campaign are simulated with a regional model (see below), the observations do not provide all input parameters needed to compute dust emission fluxes for the region. In particular, the soil size distributions of the deflatable soil particles as well as the ratio of vertical dust flux to horizontal saltation flux are still unknown. As full regional dust simulations for the period of the field experiment are computationally too expensive for testing more than very few parameter combinations, a box model version of the dust emission scheme was used to test different parameterizations. The box model computes dust emissions at the Chicha field site using the observed surface wind speeds at $2 \mathrm{~m}$ height that were reported every $2 \mathrm{~min}$. Emission fluxes (in $\mathrm{g} \mathrm{m}^{-2} \mathrm{~s}^{-1}$ ) were computed for particles with radii between $0.1 \mu \mathrm{m}$ and $750 \mu \mathrm{m}$ divided into 24 size bins. Direct emission flux measurements are not available for model validation, although measurements of dust optical thicknesses (DOTs) from the different sunphotometer instruments and retrievals of size distributions from the Cimel sunphotometer are available. To facilitate comparison with these measurements, a first-order estimate of DOTs was obtained from the computed emission fluxes with a simplified treatment of dry deposition of the emitted dust particles. When dust emission takes place in the model (i.e. when the surface wind friction velocity exceeds the threshold value during a 14-min time step), the emitted dust is distributed homogeneously in an atmospheric column of height $H$. The column is divided into 6 layers of heights $H / 6$ each. Depending on the particle size, dust falls back to the surface with the gravitational settling velocity $v_{s}=\frac{2 \rho g r^{2}}{9 \eta}$, where $\rho$ is the particle density, $r$ is the particle radius and $\eta$ is the kinematic viscosity of air. During time steps when no dust emission takes place into the atmospheric column, dust is removed from lowest layer in addition to the gravitational settling by turbulent mixing depending on the aerodynamic resistance $r_{a}=\frac{1}{\kappa u_{*}(z)} \ln \left(\frac{z}{z_{0}}\right)$ (Seinfeld and Pandis, 1997). The choice of the dry deposition scheme may have some influence on the results, in particular the diatomite flakes may not settle as quickly as the spherical particles that are the basis for the computation of the gravitational settling. However, the sensitivity of the results to these factors was not tested in these model studies. In addition to the removal by dry settling the dust is removed from the atmosphere above the Chicha site by horizontal wind transport. For the box model, this removal was approximated by assuming a residence time $\lambda=L /(1.4 u)$ (where $L$ is varied between $200 \mathrm{~km}$ and $400 \mathrm{~km}$ ) and $u$ is the $2-\mathrm{m}$ wind speed; the factor 1.4 takes into ac- count the increase of the wind speed with height. From these computations of dust removal we obtain size-resolved atmospheric dust mass loads, from which aerosol optical thicknesses $\tau$ at $500 \mathrm{~nm}$ wavelength are computed according to

$\tau=\sum_{i} \frac{3 Q_{\mathrm{ext}}\left(500 \mathrm{~nm}, r_{i}\right) M_{i}}{4 r_{i} \rho}$

where $Q_{\text {ext }}$ is the specific particle extinction efficiency, $\rho$ is the particle density and $M_{i}$ is the aerosol mass load of size fraction $i$ characterized by the effective radius $r_{i}$ (Lacis and Mishchenko, 1995). In addition to computing the temporal change of DOT at the Chicha site, the volume load of each size bin is computed from the mass load to obtain the volume size distribution for 4 individual time steps on days 4, 6, 7 and 9 March 2005; the results are compared to the retrieved volume size distribution from the Cimel sunphotometer (Todd et al., 2006). The number of layers has some influence on the modelled DOT, as the layer height implies the scales at which the particles are uniformly mixed. With the simplified box model parameterization the height of the lowest layer must be chosen high enough such that the settling velocity plus dry deposition is does not empty more than the lowest bin, and the height to which dust is vertically mixed is reasonable. The results change with the layer number when less than 6 layers are chosen, while are unaffected in the choice of larger numbers, thus we chose 6 layers as number of layers in the box model. The initial mixing height $H$ of dust during emission events is unknown, but from initial regional model results (described below) we find that that model mixes the dust up to heights between 500 and $1000 \mathrm{~m}$; tin the model $H$ was be varied between 500 and $1500 \mathrm{~m}$. . The density of diatomite is set to $2.1 \mathrm{~g} \mathrm{~cm}^{-3}$ in agreement with the measurements (it should be noted that a different measurement of the bulk density of the Bodele diatomite resulted in a lower value of $0.9 \mathrm{~g} \mathrm{~cm}^{-3}$ ).

Alfaro et al. (1997) related the size $d$ of dust particles that are released from soils through saltation to the kinetic energy of the saltating particle, which is used to break up the aggregates, the cohesion energy $E$ of the kaolinite particles was found to be an exponential function of the particle size $E=14.9 e^{(-0.53 d)}$. Similarly, here we assume that the minimum size of released particles depends on the kinetic energy of the saltators, with dust released in one or two size modes. With the assumption that dust produced during BoDEx originates from breaking up of saltating diatomite flakes, we do not make a-priori-assumptions for the dominant size mode of soil particles that become available for saltation. While soil particles with size modes at $100 \mu \mathrm{m}$ are easily lifted from the ground, soil particle diameters of up to $5 \mathrm{~mm}$ were allowed in the box model to account for the possibility of mobilization of macroscopic diatomite flakes. We assume that the mass of the produced dust is directly proportional to the mass of the saltators, and allow for one or two size modes of disaggregated dust particles in the clay and silt size range, between 1 
and $20 \mu \mathrm{m}$. We also test reducing the kinetic energy necessary for disaggregation of the saltating particles compared to the value derived in Alfaro et al. (1997) to account for possibly lower binding energies of diatomite compounds compared to clay aggregates.

The emission factor $\alpha$ that related the horizontal flux of saltating particles to the vertical dust flux is computed aposteriori by calibrating the model results with the observed dust optical thickness, such that the mean value of aerosol optical thickness measurements agreed with the mean value of the DOT model results at those time intervals for which measurements were available.

Two series of experiments were carried out with the box model. In the first series the model used the observed $2 \mathrm{~m}$ wind at the field site as model input. The parameters used to compute DOT in the box model were varied as follows: (monomodal) soil particle size: $200 \mu \mathrm{m}, 1000 \mu \mathrm{m}, 2500 \mu \mathrm{m}$, and $5000 \mu \mathrm{m}$; dust particle size-mode diameter: $2 \mu \mathrm{m}, 3 \mu \mathrm{m}$, $4 \mu \mathrm{m}$ and $20 \mu \mathrm{m}$ or $30 \mu \mathrm{m}$; standard deviation: 2,3 , 4; particle density: $1 \mathrm{~g} \mathrm{~cm}^{-3}, 2 \mathrm{~g} \mathrm{~cm}^{-3}, 2.65 \mathrm{~g} \mathrm{~cm}^{-3}$, particle cohesion energy: reducing the value from Alfaro et al (1997) between factors $1,5,20,50$, mixing height $\mathrm{H}: 500 \mathrm{~m}, 1000 \mathrm{~m}$, $1500 \mathrm{~m}$ and upwind transport distance $L: 200 \mathrm{~km}, 300 \mathrm{~km}$, $400 \mathrm{~km}$. The second series of box model experiments was carried out using the surface wind speeds that were extracted from the regional model (see below) at the location of the field site. Here, the parameters above were kept constant at a combination of values that gave the best results for the first series of experiments. Here, experiments were carried out to reduce the difference in the results that was caused by the differences in the wind speeds, by reducing the threshold friction velocity for dust emission, and by testing a subgriddscale parameterization for the surface wind speed from the regional model.

We computed a statistic $A$ (as defined in Cakmur et al., 2006) to quantify the agreement between the modelled optical thickness time series and size distribution for 6 time intervals at the Chicha site with the observations

$$
A=\frac{\frac{1}{N_{M}} \sum_{i}\left(X_{i}^{M}-X_{i}^{O}\right)^{2}}{\frac{1}{2 N_{M}}\left[\sum_{i}\left(X_{i}^{M}\right)^{2}+\sum_{i}\left(X_{i}^{O}\right)^{2}\right]}
$$

where $X_{i}^{O}$ are the observations, $X_{i}^{M}$ are the modelled values, and the sum is over all $N_{M}$ observations. $A=1$ indicates no agreement between the model and the observations. The particle size distributions from the sunphotometer retrievals are reported as volume distribution at 22 particle radii, the comparison with the model results was performed by comparing the relative volume distribution at those radii where the results of the model size bins were interpolated to the radii reported for the retrieval to compute $\mathrm{A} ; A=0$ indicates perfect agreement of model and measurements.

\subsection{Regional model LM MUSCAT}

LM MUSCAT is a parallelized multi-scale regional model consisting of the non-hydrostatic Lokal-Modell (LM; Doms and Schättler, 1999), which is the central part of the operational weather forecast model of the German weather service (Deutscher Wetterdienst) as meteorological driver, and the online-coupled 3-D chemistry tracer transport model MUSCAT (MUltiScale Chemistry Aerosol Transport Model: Knoth and Wolke, 1998, Wolke und Knoth, 2000). LM uses with initial and boundary conditions from the global model GME of the DWD. MUSCAT is based on timedependent mass balance equations considering chemical reactions and microphysical processes, and is used for simulations of physico-chemical and aerosol dynamic fields on the mesoscale. Advection is computed by a third-order upstream scheme, temporal integration is carried out by an implicitexplicit method (Wolke and Knoth, 2000). The dust emission fluxes in this model are computed with surface winds and soil moisture fields from the meteorological model LM, dust is transported as passive tracer in 5 independent size bins covering the size range from $0.1-25 \mu \mathrm{m}$ radius with the MUSCAT tracer scheme. The aerosol deposition parameterization in LM-MUSCAT is modified to account for dust aerosol particle density and washout efficiency. The performance of this regional dust model so far has been tested for two well-documented events of Saharan dust transport to Europe in August and October 2001 (Heinold et al., 2006 ${ }^{1}$ ). For the period of the BoDEx field study, a horizontal resolution of $7 \mathrm{~km}$ was used for the area between the coordinates $\left(12.60^{\circ} \mathrm{N} ; 11.63^{\circ} \mathrm{E}\right),\left(10.30^{\circ} \mathrm{N} ; 25.00^{\circ} \mathrm{E}\right),\left(22.17^{\circ} \mathrm{N}\right.$; $\left.29.08^{\circ} \mathrm{E}\right),\left(25.09^{\circ} \mathrm{N} ; 12.10^{\circ} \mathrm{E}\right)$, which covers the surroundings of the Chicha site as well as a considerable area upstream, ensuring that dust transported to the field site is simulated as well as the locally produced dust (Fig. 1). The model has 40 vertical layers, the lowest layer reaching $68 \mathrm{~m}$ above ground. Vegetation cover that inhibits dust deflation plays a minor role in the model region, the vegetation cover is calculated using satellite observations from the Global Inventory Modeling and Mapping Studies (GIMMS) normalized difference vegetation index (NDVI) data sets (Tucker et al., 2005). Soil texture data outside of the preferential source region, where they are derived from the best match of the box model results, are taken from Zobler (1986). Surface roughness data for the regional model are derived from the POLDER bidrectional reflectance measurements (Marticorena et al., 2004), which are available at $1 / 15^{\circ}$ resolution. The surface roughness was assumed to be $0.001 \mathrm{~cm}$ for model gridcells where surface roughness measurements were not available and topography and land cover data in-

\footnotetext{
${ }^{1}$ Heinold, B., Helmert, J., Hellmuth, O., Wolke, R., Ansmann, A., Marticorena, B., Laurent, B., and Tegen, I.: Regional Modeling of Saharan Dust Events using LM-MUSCAT: Model Description and Case Studies, J. Geophys. Res., submitted, 2006.
} 
dicate the presence of a preferential source. Deposition of the large dust particles is mostly driven by dry deposition, the stronger gravitational settling of larger particles leads to changes in the size distribution of atmospheric dust during transport. From the size-resolved dust concentrations, dust optical thicknesses are computed as described above. The optical properties (extinction efficiency, single scattering albedo, and asymmetry parameter) used to compute changes in radiative fluxes in the LM are calculated for each size bin with the refractive derived from the Cimel sunphotometer measurements taken during the Bodélé field study (Todd et al., 2006) at visible wavelengths, and from Volz (1973) at infrared wavelengths employing Mie theory based on an algorithm by Mishchenko et al. (2002) (Table 1). Computed optical properties are adopted in the LM radiation scheme by spectral integration for each of the three solar and five longwave IR bands (Table 1). The change in energy fluxes is allowed to impact on the meteorology, and feeds back on dust emissions and atmospheric distributions of the dust. The BoDEx case was simulated twice in the regional model, once computing soil dust as radiatively active tracer, which impacts on the meteorological fields of LM, and once without dust. LM takes into account the radiative forcing of five aerosol types in terms of constant optical thickness distributions, for these model experiments this prescribed forcing was turned off for the desert aerosol type.

\subsection{Global emissions, offline model}

The parameterization for computing size resolved emissions for the Bodélé "hot spot" dust source that are derived in this work is implemented into the global offline dust model, which is described in detail in Tegen et al. (2002). Dust emissions and transport are computed with meteorological fields from the ECMWF ERA15 reanalysis. The model uses satellite derived surface roughness length data from microwave backscattering observations (Prigent at al., 2005) as input parameter for computing global-scale dust emissions, which are available at 0.25 degree resolution for unvegetated regions. Dust emissions were computed at $0.5^{\circ}$ spatial resolution with a 6-h time step, the emission fields are then integrated to $3.75^{\circ} \times 5^{\circ}$ horizontal resolution, which is the resolution of the tracer transport model. Dust deposition is by dry and wet deposition as described in Tegen et al. (2002). For the year 1987 dust emissions were computed with two different dust source parameterizations for hot spot areas, applying the Bodélé parameterization for all global hot spot sources defined as enclosed topographic depressions. In addition, one model experiment was carried out with dust emissions from the Bodélé region from $15^{\circ} \mathrm{E}-20^{\circ} \mathrm{E}$ and $12^{\circ} \mathrm{N}-18^{\circ} \mathrm{N}$ set to zero to evaluate the contribution of Bodélé dust to the global and regional dust optical thickness.
Table 1. Optical properties of the dust particles used in the regional model LM-MUSCAT for the 5 size bins.

\begin{tabular}{|c|c|c|c|c|}
\hline $\begin{array}{l}\text { Spectral Interval } \\
(\mu \mathrm{m})\end{array}$ & $\begin{array}{l}\text { Effective radius } \\
(\mu \mathrm{m})\end{array}$ & $Q_{\text {eff }}$ & $\omega_{0}$ & $g$ \\
\hline \multirow[t]{5}{*}{$0.245-0.700$} & 0.17 & 1.788 & 0.988 & 0.660 \\
\hline & 0.5 & 3.059 & 0.970 & 0.705 \\
\hline & 1.5 & 2.330 & 0.920 & 0.784 \\
\hline & 4.6 & 2.137 & 0.830 & 0.851 \\
\hline & 13.8 & 2.068 & 0.701 & 0.903 \\
\hline \multirow[t]{5}{*}{$0.700-1.530$} & 0.17 & 0.448 & 0.990 & 0.405 \\
\hline & 0.5 & 2.995 & 0.994 & 0.707 \\
\hline & 1.5 & 2.490 & 0.976 & 0.679 \\
\hline & 4.6 & 2.218 & 0.940 & 0.789 \\
\hline & 13.8 & 2.105 & 0.860 & 0.845 \\
\hline \multirow[t]{5}{*}{$1.530-4.642$} & 0.17 & 0.042 & 0.809 & 0.104 \\
\hline & 0.5 & 1.101 & 0.961 & 0.548 \\
\hline & 1.5 & 3.168 & 0.976 & 0.694 \\
\hline & 4.6 & 2.398 & 0.923 & 0.743 \\
\hline & 13.8 & 2.179 & 0.850 & 0.830 \\
\hline \multirow[t]{5}{*}{$4.642-8.333$} & 0.17 & 0.019 & 0.042 & 0.010 \\
\hline & 0.5 & 0.087 & 0.308 & 0.094 \\
\hline & 1.5 & 0.980 & 0.650 & 0.551 \\
\hline & 4.6 & 2.746 & 0.729 & 0.791 \\
\hline & 13.8 & 2.337 & 0.578 & 0.891 \\
\hline 8.333-9.009; & 0.17 & 0.048 & 0.002 & 0.004 \\
\hline \multirow[t]{4}{*}{$10.309-12.500$} & 0.5 & 0.159 & 0.042 & 0.036 \\
\hline & 1.5 & 0.932 & 0.355 & 0.326 \\
\hline & 4.6 & 2.727 & 0.508 & 0.718 \\
\hline & 13.8 & 2.389 & 0.488 & 0.878 \\
\hline \multirow[t]{5}{*}{$9.009-10.309$} & 0.17 & 0.057 & 0.006 & 0.007 \\
\hline & 0.5 & 0.235 & 0.119 & 0.070 \\
\hline & 1.5 & 2.286 & 0.444 & 0.319 \\
\hline & 4.6 & 2.842 & 0.501 & 0.680 \\
\hline & 13.8 & 2.435 & 0.562 & 0.800 \\
\hline \multirow[t]{5}{*}{$12.500-20.000$} & 0.17 & 0.034 & 0.001 & 0.002 \\
\hline & 0.5 & 0.105 & 0.014 & 0.016 \\
\hline & 1.5 & 0.483 & 0.201 & 0.151 \\
\hline & 4.6 & 2.305 & 0.479 & 0.601 \\
\hline & 13.8 & 2.629 & 0.493 & 0.842 \\
\hline \multirow[t]{5}{*}{$20.000-104.515$} & 0.17 & 0.017 & 0.000 & 0.001 \\
\hline & 0.5 & 0.053 & 0.003 & 0.005 \\
\hline & 1.5 & 0.207 & 0.077 & 0.049 \\
\hline & 4.6 & 1.850 & 0.430 & 0.306 \\
\hline & 13.8 & 2.971 & 0.488 & 0.641 \\
\hline
\end{tabular}

\section{Results}

\subsection{Box model results}

A series of box model experiments were carried out, in particular to evaluate which soil size and initial dust size distribution leads to agreement with the sunphotometer observations of aerosol optical thickness and size distribution retrievals. The size distribution from the sunphotometer retrievals is not used directly as model input, as initially 
deflated large particles settle quickly from the atmosphere, thus the observed atmospheric size distribution does not necessarily reflect the initial size distribution of the deflated particles. We compare the DOT model results that are derived in this work is with measured aerosol optical thicknesses (Fig. 2) at the field site, and compare the modelled size distributions with retrievals derived from the Cimel sunphotometer measurements on days 4, 6, and 7 March (Fig. 3a-d). Figure $3 \mathrm{e}$ shows the results for 9 March, which is not used for the computation of the statistics A as the retrieval is unreliable at this time, but this retrieval at the beginning of the dust storm indicates a possible presence of dust particles larger than $2 \mu \mathrm{m}$. The retrieval at this day is problematic because of the possibility of stray light saturation of the sky radiances corresponding to small scattering angles. Also, later on 9 March, the presence of cirrus clouds was evident, i.e.the presence of cloud contamination in the inversions of the sunphotometer measurements may have biased the results at this time. Good agreement, with values for $A$ ranging between 0.25 and 0.3 (computed as arithmetic mean of the agreement factors $A$ for calibrated DOT and for normalized size distributions at the 4 selected times), is obtained for a variety of parameter combinations with saltator particle sizes ranging between 100 and $500 \mu \mathrm{m}$ radius, and dust size modes for combinations of particle radii between 1 and $15 \mu \mathrm{m}$. The best results were obtained for mixing height $\mathrm{H}$ of $1000 \mathrm{~m}$ and distance $\mathrm{L}$ of $400 \mathrm{~km}$. However, the observations are so far insufficient to decide on a best parameter combinations for the soil and dust particle sizes, as the results in statistics A show only subtle differences for different parameter combinations. In contrast, the agreement between box model results and observations is worse for the size parameterization from Tegen et al. (2002) (see Sect. 3.1), with a "best" minimum value of $A=0.41$. The agreement is generally better for cases where the aggregate binding energy of the particles and thus the kinetic energy of the saltators that is necessary to enable the release of the fine dust are reduced by about one order of magnitude compared to the value derived for kaolinite aggregates in Alfaro et al. (1997). A parameter combination that give good agreement $(\mathrm{A}=0.26)$ is for soil particle size of $200 \mu \mathrm{m}$, dust sizes of $2 \mu \mathrm{m}(30 \%)$ and $20 \mu \mathrm{m}(70 \%)$ (sizes as diameters), and kinetic energy required to release fine dust reduces by the factor of 20 compared to Alfaro et al. (1997) (Figs. 2 and 3). The DOT (Fig. 2) agrees well for all days except on the afternoon of 9 March, when the model results lie below the sunphotometer retrievals. Observations indicated the presence of cirrus clouds at that time, which may have led to an overestimate in aerosol optical thickness retrievals. Similarly good agreement is found when assuming a mono-modal dust size distribution with a mode radius at $1 \mu \mathrm{m}$, but a larger geometric standard deviation of $3 \mathrm{com}-$ pared to the value of 2 in the original parameterization of the size distribution $(\mathrm{A}=0.25)$ (Fig. 3). The comparison between modelled and retrieved size distribution clearly shows that parameterization for dust production in hot spot areas

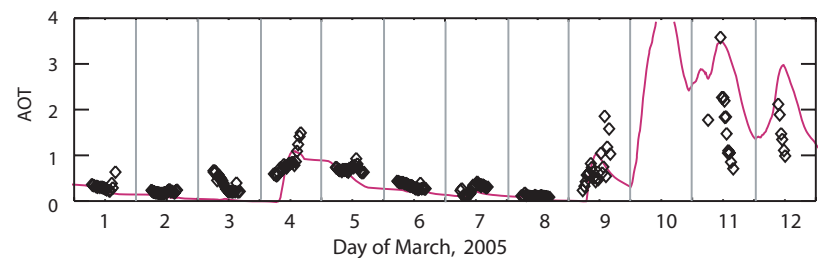

Fig. 2. Dust optical thickness computed with the box model (red line) compared to sunphotometer measurements at the Chicha site (black symbols). The result is shown for a monomodal soil particle size of $200 \mu \mathrm{m}$, dust sizes of $2 \mu \mathrm{m}(30 \%)$ and $20 \mu \mathrm{m}(70 \%)$, and kinetic energy required to release fine dust reduces by the factor of 20 compared to Alfaro et al.(1997), particle density of $2 \mathrm{~g} \mathrm{~cm}^{-} 3$ dust mixing height $H=1000 \mathrm{~m}, L=400 \mathrm{~km}$ (see Sect. 3.1).
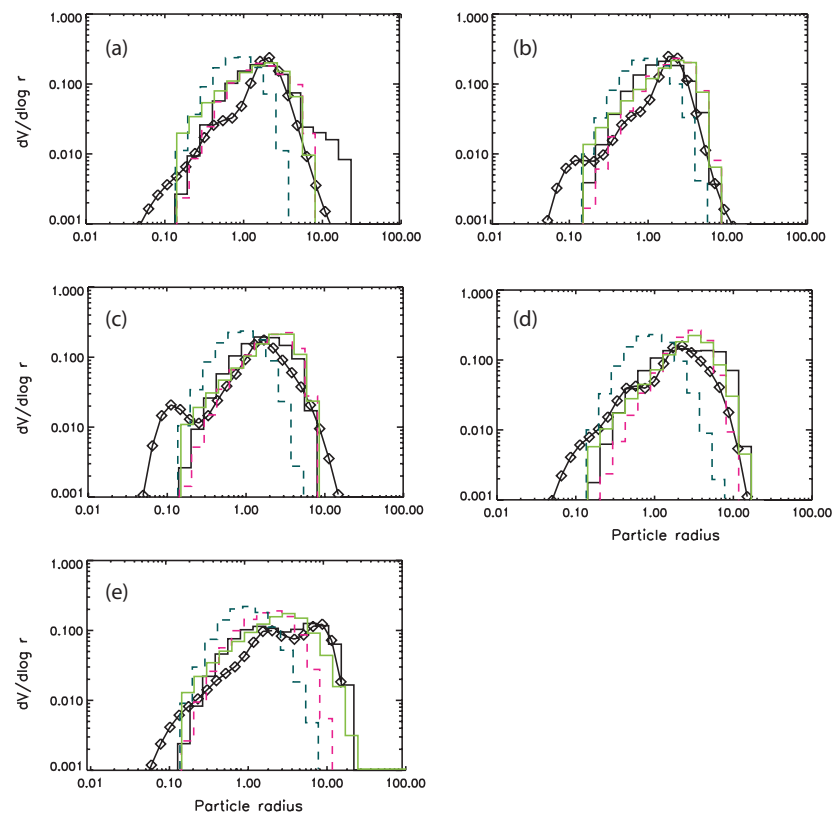

Fig. 3. Size distribution for date and times in March 2005: 4 March, 06:30 UTC (a); 6 March, 07:40 UTC (b); 7 March, 07:40 UTC (c); 7 March, 14:17 UTC (d); 9 March, 09:58 UTC (e). Comparison of Cimel retrievals (symbols) with the size distribution from the best result from box model with (i) dust sizes modes of 1 and $10 \mu \mathrm{m}$ radius and geometric standard deviation of 2, (black histograms); (ii) one dust size mode at $1 \mu \mathrm{m}$ radius but with a geometric standard deviation of 3 (green histogram); (iii) as (i) but higher kinetic energy of saltating particles required for breaking up aggregates (pink dashed histogram); (iv) parameterization from Tegen et al. (2002) (blue dashes histogram).

following Tegen et al. (2002) leads to dust size modes which are too small compared to the observations (Fig. 3). Still, the results remain similar for different parameterizations of soil properties.

While the results shown in Figs. 2 and 3 were derived using the wind speed measurements that were taken during the field experiment, we use the box model also to test the 

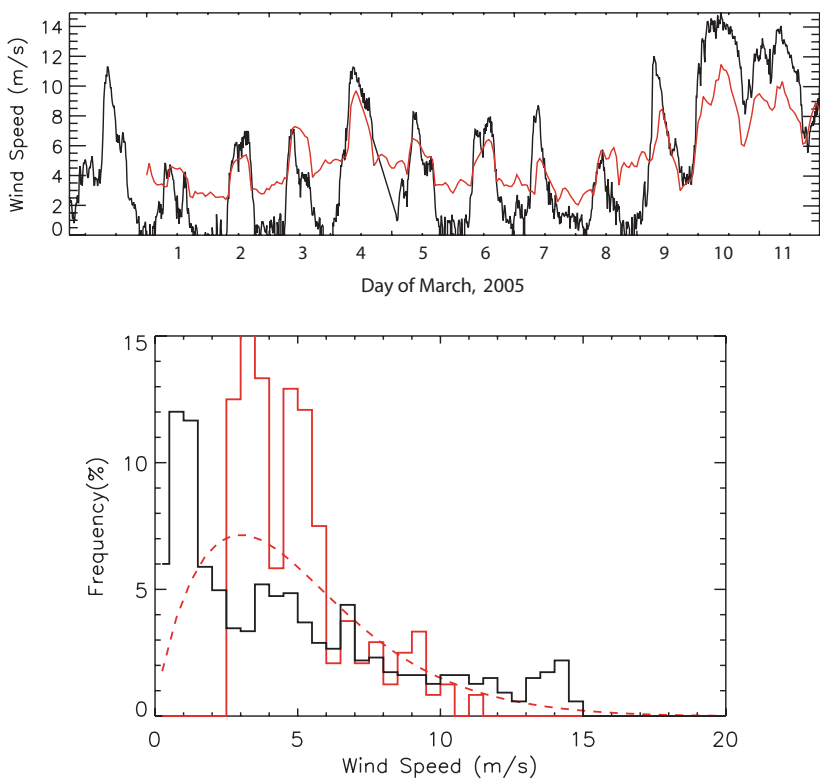

Fig. 4. Time dependent $2 \mathrm{~m}$ wind speed measurements (black line) compared to $10 \mathrm{~m}$ surface wind speed results from the LM experiment (red line; a) and the histogram of frequencies of the wind speeds occurring in the measurements (black) and in LM (red) between days 60 to 72 (b). Also shown is the wind speed distribution of the model winds modified by a Weibull probability distribution (dashed red line).

performance of the surface wind speeds from the regional model LM. The comparison of surface wind speed observations and hourly LM model results computed with $7 \mathrm{~km}$ horizontal resolution at the location of the Chicha site shows that the regional model underestimates the peak wind speeds at daytime during dust storm days, and overestimates nighttime winds (Fig. 4a). A possible reason for this discrepancy is that the LM does not form a well-defined boundary layer. The histogram of measured and modelled wind speed data (Fig. 4b) supports the finding that neither the minimum nor maximum wind speeds are matched by the model, even with the high spatial resolution of $7 \mathrm{~km}$. The maximum model wind speeds in the LM do not exceed $11.5 \mathrm{~m} \mathrm{~s}^{-1}$, while in ca. $15 \%$ of the time intervals during the BoDEx period the measured 2-m wind speeds are above $10 \mathrm{~m} \mathrm{~s}^{-1}$, compared to $3 \%$ of the model winds for the same time period. Even at this high resolution, the error in modelled surface wind speeds is causing errors in the dust emission computation for the dust storm days, since the dependence of dust emission on surface wind speeds is highly non-linear.

In the second series of box model experiments we simulated dust emissions with the box model using hourly 10$\mathrm{m}$ wind speeds from the LM regional model in addition to the computations using the observed winds (Fig. 5). As described in Sect. 3.2 above, the emission factor $\alpha$ was chosen such that average dust optical thicknesses from the model
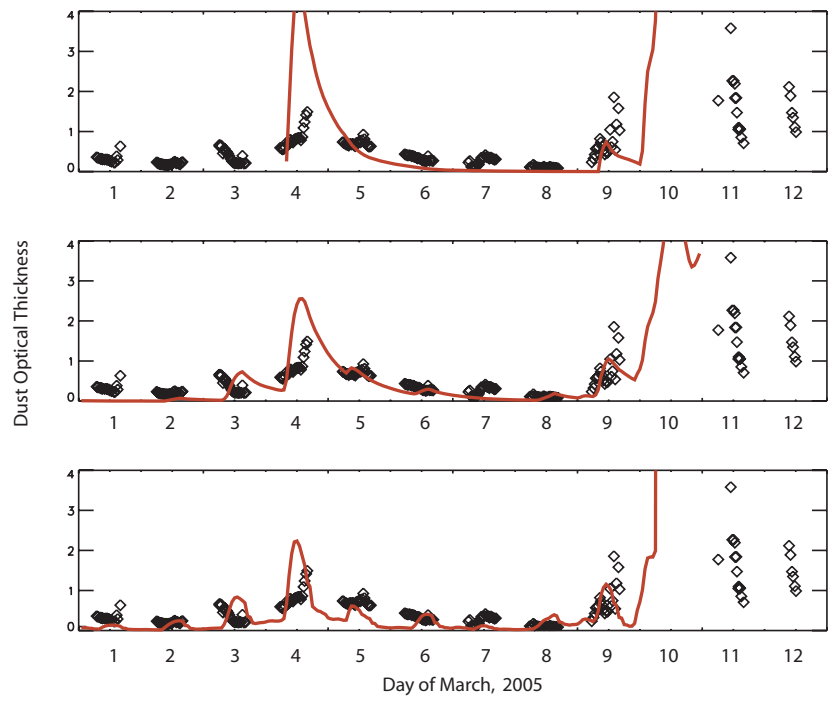

Fig. 5. Sensitivity tests of the modelled DOT (red line) at Chicha with dust emissions computed from the modelled LM surface winds and DOTs computed with the box model. Results are shown for DOT the best estimate parameter combination computed with the surface winds taken from the LM model extracted at the location of the field site (a); as a but with minimum threshold wind friction velocity reduced by the factor 0.66 (b); and as a but using a Weibull distribution to describe subgridscale variability of surface winds (c); compared to sunphotometer measurements of DOT (black symbols).

matched observations for those times when measurements were available. Because of the low maximum LM wind speeds, the computation of dust emissions directly with the LM winds rather than with the observed wind speeds produces a DOT time series that is mismatched compared to the observations (Fig. 5a). In order to match average DOT, the model produces much too high optical thickness on 4 March compared to the observations, while being too low between this event and the dust storm starting on 9 March. Also, the increase in dust optical thicknesses during the strong dust event on 9 March starts too late in the model when compared to the observations. The statistics $A$ for the comparison of modelled and observed optical thicknesses equals 1 for this case. Using lower threshold velocities for initiation of dust emissions improves the model results compared to the observations. For the current event we find that the use threshold friction velocities lowered by a factor of 0.66 results in a DOT time series that matches the observations satisfactorily (Fig. 5b) with $A=0.69$. This approach to account for underestimation of maximum wind speeds had been used in the global dust model in Tegen et al. (2004) and Prigent et al. (2005), where threshold friction velocity for dust emission was lowered to a value that ensured agreement of the number of dust events in the model with globally observed dust storm frequencies (Engelstaedter et al., 2003). For the condition at the Bodele site this is equivalent to a decrese in 


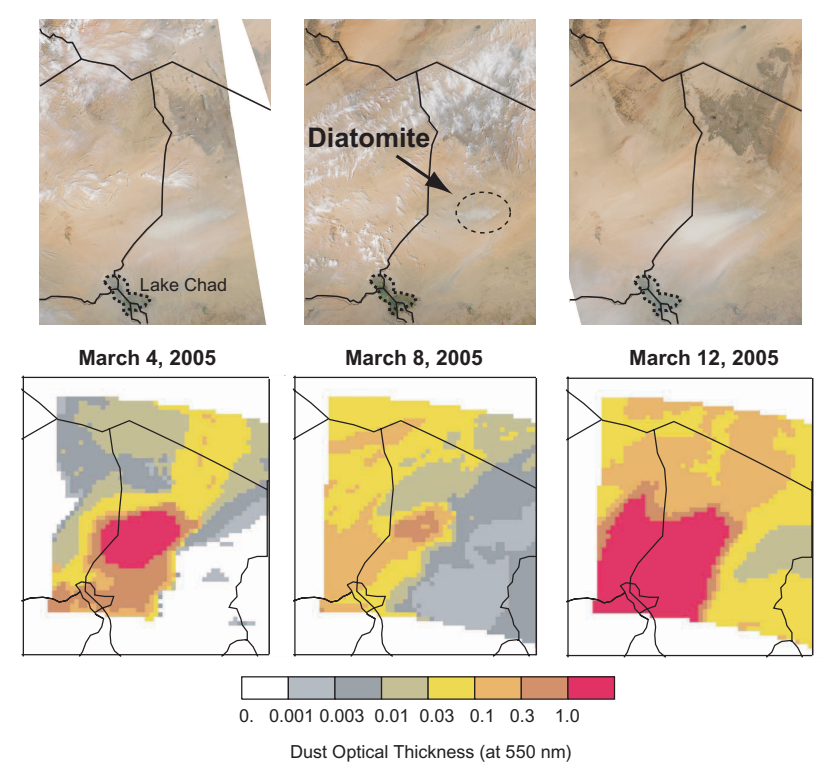

Fig. 6. Dust distribution on days 4,8 and 12 March as seen by MODIS (upper panels) and dust optical thickness simulated with the regional dust model (lower panels).

threshold surface wind speeds from $7.3 \mathrm{~m} \mathrm{~s}^{-1}$ (for the case shown in Fig. 5a) to $4.8 \mathrm{~m} \mathrm{~s}^{-1}$ (depicted in Fig. 5b). As a different approach to account for the underestimation of peak wind speeds, several global dust models describe surface wind speed distributions using probability density functions for computation of dust emissions in order to account for subgriscale variability of surface winds (Lunt and Valdes, 2002; Cakmur et al., 2003). Grini et al. (2005) use a Weibull probability distribution for surface wind speed which is described by a shape factor $k=0.94 \cdot u^{-2}$ and a scale factor $c=u / \Gamma(1+1 / k)$ where $\mathrm{u}$ is the surface wind speed at $10 \mathrm{~m}$ and $\Gamma$ is the Gamma function. We tested the emission model assuming this Weibull probability distribution for the modelled surface winds (Fig. 5c, $A=0.71$ ). The resulting modelled dust optical thicknesses match the observations well for the most part of the BoDEx period, but increase to unrealistically high DOT values of more than 100 for the strong dust event after 9 March, which indicates that the subgridscale variability of high surface wind speeds (above $11 \mathrm{~m} \mathrm{~s}^{-1}$ ) does not follow the same type of Weibull distribution as for lower wind speeds.

\subsection{Regional model results}

The emission parameterization in the regional dust model was chosen such that the size of saltating particles was represented by a lognormal mono-modal size distribution represented by a $100 \mu \mathrm{m}$ mode radius. The particles degrade during saltation into smaller dust particles consisting of $70 \%$ particles with a mode radius of $10 \mu \mathrm{m}$, and $30 \%$ particles with $1 \mu \mathrm{m}$ mode radius. To account for the underestima-

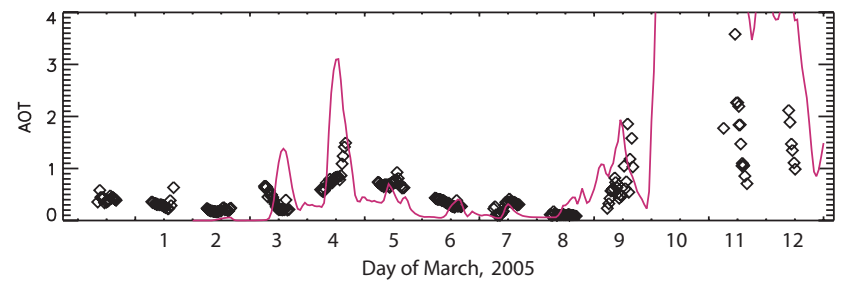

Fig. 7. Dust optical thickness computed with LM-MUSCAT (red line) compared to sunphotometer measurements at the Chicha site (black symbols).

tion of peak wind speeds in the model, the threshold friction velocity was lowered by 0.66 according to the box model results, and we assumed a 20 -fold smaller kinetic energy needed to break up the saltating diatomite particles compared to the results from Alfaro et al. (1997) derived for break-up of clay aggregates. The factor $\alpha$ of $1.8 \times 10^{-6} \mathrm{~cm}^{-} 1$ was chosen to match the results from the box model for the preferential source. The dust particle density was set to a value of $2 \mathrm{~g} \mathrm{~cm}^{-3}$. In summary, the "new" parameterization updated the "old" "preferential source type" from Tegen et al. (2002) by increasing the mode radius of the soil particles from 7.5 to $100 \mu \mathrm{m}$, adding a second dust mode with a radius of $10 \mu \mathrm{m}$ compared to using only a $1 \mu \mathrm{m}$ dust radius, decreasing particle density from $2.65 \mathrm{~g} \mathrm{~cm}^{-3}$ in Tegen et al. (2002) to $2 \mathrm{~g} \mathrm{~cm}^{-3}$, and decreasing $\alpha$ from $1 \times 10^{-5} \mathrm{~cm}^{-} 1$ to 1.8 $\times 10^{-6} \mathrm{~cm}^{-} 1$. While aerosol retrievals by remote sensing over the highly reflecting desert surface are difficult, MODIS true colour images are available for the BoDEx period for the Chad region (Fig. 6, top). Dust can by distinguished by white streaks in these images on the days 4 March, 9 March and 10-12 March, while on 8 March the low atmospheric dust contents allows the diatomite layer to be distinguished towards the lower right part of the image. The comparison of the retrieval with regional model results for the days 4,8 , and 12 March (Fig. 6, bottom) shows a good qualitative agreement of the spatial extent and intensity of the dust clouds.

Comparing the DOTs simulated with the regional model for the BoDEx events shows reasonable agreement between the model and measurements (Fig. 7). On 4 March, dust emissions are overestimated by the model, and the strong increase in DOT on 10 March occurs too early in the model. The overestimate of dust optical thickness on 4 March indicates a possible overcompensation of the adjustment of the wind speed threshold on this day, and shows the need for improvement in the computation of wind friction velocities in this region. The overestimation of night-time wind speeds in LM does not affect the dust emissions, since the threshold friction velocity for initiating dust emission is not reached. The total dust emission for the days with the strongest dust emission, 10 to 12 March computed by the regional model is $104 \mathrm{~g} \mathrm{~m}^{-2}$ at the Chicha site. In comparison, Todd et al. (2006) estimate an emission of $324 \mathrm{~g} \mathrm{~m}^{-2}( \pm 40 \%)$ for 
those days from the Cimel sunphotometer retrievals of dust volume and assuming the total exposed diatomite layer of $\sim 10.8 \times 10^{9} \mathrm{~m}^{2}$ equally contributes to dust production. The discrepancy of the emission estimates can be partly explained by the underestimate of the maximum wind speeds during the days when the observed wind speeds exceed $10 \mathrm{~m} \mathrm{~s}^{-1}$ in the model, and the uncertainty of the assumption that the whole diatomite layer is equally effective in producing dust aerosol.

The change with time of the vertical distribution of the dust extinction from the model at the Chicha site is shown in Fig. 8a. During emission events dust is mixed up to approximately $1 \mathrm{~km}$ into the atmosphere. The temperature change due to dust (Fig. 8b) computed as difference in modelled LM temperature for the case where dust is radiatively interactive and the LM results without dust added as radiatively active tracer shows a distinct cooling at daytime at the lower part of the dust cloud for the dust storm days. At night-time, dust causes a slight warming in the order of $1 \mathrm{~K}$ near the surface due to its absorption of outgoing thermal radiation.

The difference between net radiation fluxes at the top of the atmosphere for the model case including dust radiative forcing and the case without dust impact on radiation depends on the dust optical thickness itself, at the Chicha site the computed net radiative flux difference changes from $-9.2 \mathrm{~W} \mathrm{~m}^{-2}$ on 8 March, 12:00 UTC when dust was low, to $-219.3 \mathrm{~W} \mathrm{~m}^{-2}$ on 10 March, 12:00 UTC. At the surface, this difference in radiative fluxes between the two experiments increased from -44.7 to $-511.6 \mathrm{~W} \mathrm{~m}^{-2}$. The modelled change in surface solar radiation of $590 \mathrm{~W} \mathrm{~m}^{-2}$ between these days is in good agreement with the decrease by $562 \mathrm{~W} \mathrm{~m}^{-2}$ of the measured solar radiation fluxes, considering the uncertainties in these measurements. If dust aerosol is included and the radiative forcing by dust permitted to influence model temperatures, we find that the measured daytime temperatures and their change with time is much better matched by the model compared to the model results without dust forcing after 9 March when the DOT was greatly increased (Fig. 9). The underestimate of daytime temperatures on March 4 for the model with radiatively interactive dust is explained by the overestimate in modelled DOT compared to the observations. We directly compare the surface temperatures from the regional model and the measurements taken at the field site. Between the days 8 March and 10 March before and after the start of the dust storm - the maximum daytime temperature decreases by about $12 \mathrm{~K}$. In the model run without radiative forcing by dust, the maximum temperature decrease between these days is only $6 \mathrm{~K}$ lower than the observations. In contrast, the $11 \mathrm{~K}$ temperature decrease for the model run which includes dust forcing agrees with the observation (Fig. 9). Thus, the forcing by dust aerosol accounts for about half of the observed temperature decrease for the dust storm event, confirming the assumption stated by Todd et al. (2006). The overestimate of night-time temperatures by both model experiments may be caused by the inability of the models to produce a well defined boundary layer. The max-
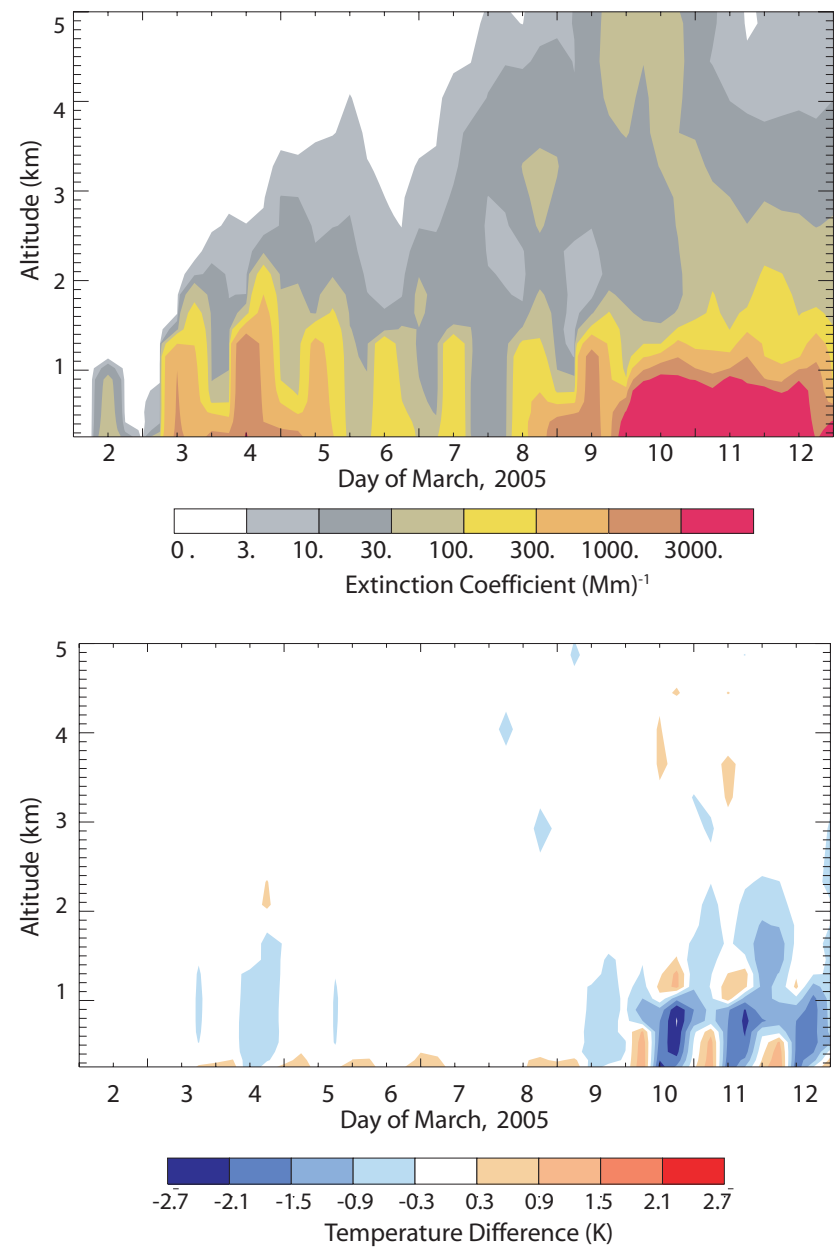

Fig. 8. Vertical distribution of aerosol extinction (top) and temperature change due to the direct radiative effect of dust (bottom); as difference of the regional model results including dust forcing and results from the model without including dust.

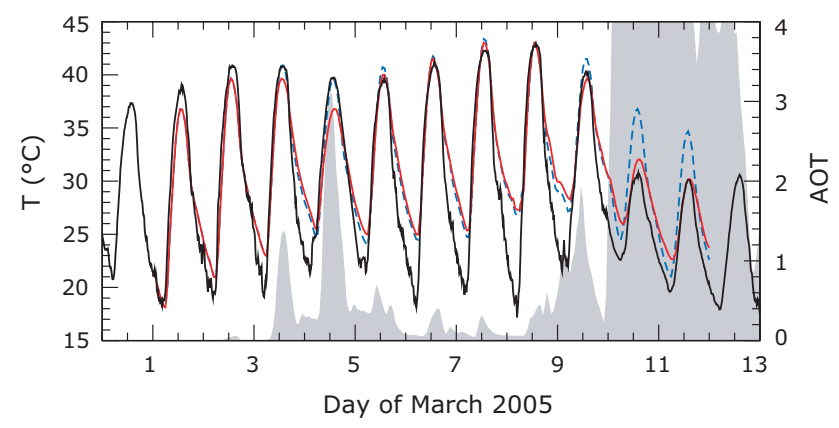

Fig. 9. 2-m Temperature difference of the regional model results including dust forcing (red line) and results from the model without including dust (blue dashed line) compared to $2 \mathrm{~m}$ temperature measurements at the Chicha site (black line). The grey shaded area indicates the modelled dust optical thickness. 


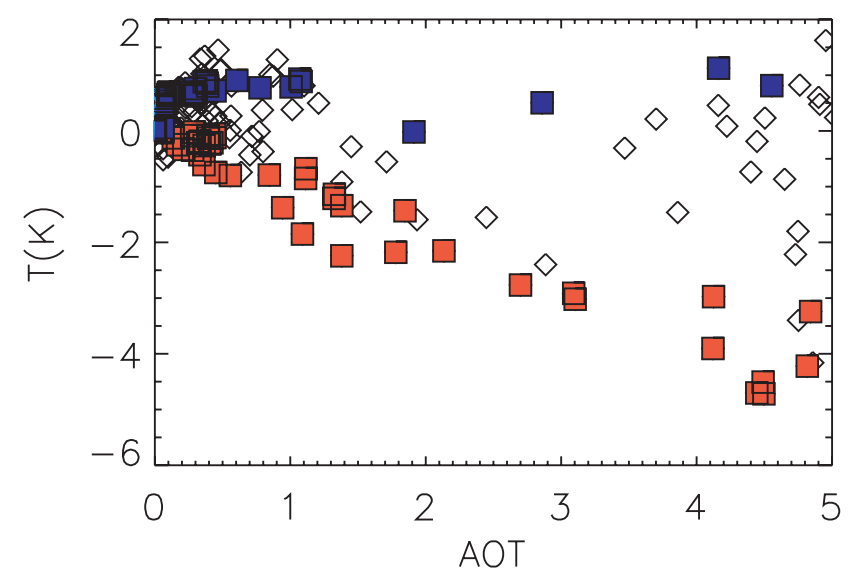

Fig. 10. Difference in modelled hourly $2 \mathrm{~m}$ temperatures between the regional model experiment including dust and the modelled temperatures when dust is not included depending on dust optical thickness; the maximum day (orange) and minimum night temperatures (blue) are shown as squared symbols.

imum night-time increase and maximum daytime decrease of 2-m temperatures for the model run including dust at the Chicha location compared to DOT (Fig. 10) indicate that dust optical thicknesses above 0.5 do not lead to a further increase in night-time temperatures, while the daytime maximum reduction in modelled surface temperatures caused by dust is nearly linearly dependent on the DOT.

\subsection{Global model results}

It is still unclear to what extent the parameterization used for the dust emission from the Bodélé can be extrapolated to other "hot spot" dust emission regions. However, when applying the new parameterization of Bodélé dust emission derived with the box model globally to all "hot spot" dust deflation areas from Tegen et al. (2002), global annual dust emissions increase by about a factor of 2 from $1600 \mathrm{Mt} \mathrm{year}^{-1}$ to

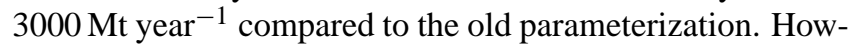
ever, this increase mostly occurs in the particle size range between 10 and $1000 \mu \mathrm{m}$ radius, while emission fluxes of smaller particles, which can be transported over large distances, remain nearly the same compared to the earlier parameterization. The modelled optical thickness distribution and concentration of far-travelled dust is therefore not greatly affected by implementing the new parameterization on the global scale beyond the immediate regions containing large dust hot spots (Fig. 11). To test the contribution of the dust from the Bodélé region to the total dust emerging from North African sources, we compare two model runs for the example year 1987, with dust emissions from the Bodélé area set to zero in $15^{\circ} \mathrm{E}-20^{\circ} \mathrm{E}$ and $12^{\circ} \mathrm{N}-18^{\circ} \mathrm{N}$. The percent difference in dust optical thickness for these two experiments (Fig. 12) show that Bodélé dust plays an important role in the southern Sahara, the Sahel, the Gulf of Guinea and equatorial At-
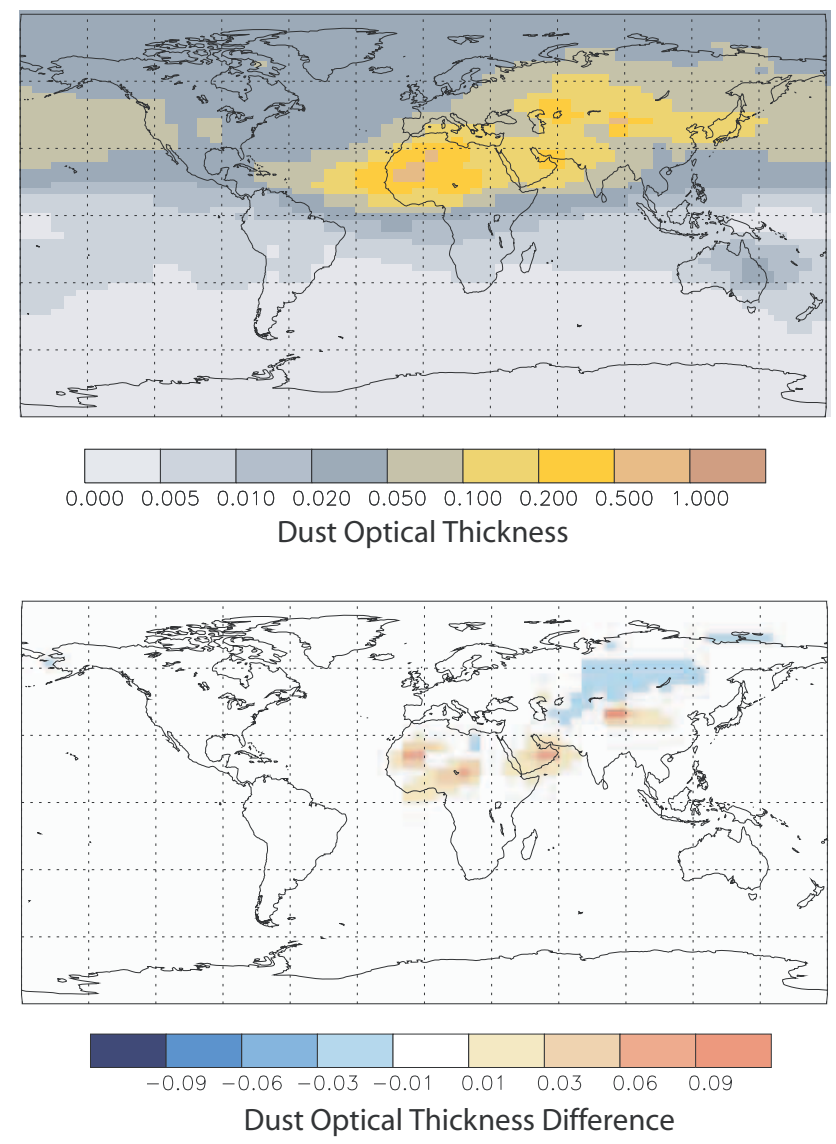

Fig. 11. Annual average modelled global dust optical thickness as annual mean for the example year 1987 computed with TM3/ERA15 (top panel) and the difference between the modelled annual dust optical thickness for the year 1987 computed with the dust emission parameterization for preferential sources from this publication and the annual dust optical thickness for the same year computed with the parameterization from Tegen et al. (2002) (lower panel).

lantic and the Amazon basin in all seasons except northern Hemisphere summer. At that time, the peak wind speeds in the global model are not sufficient to produce large amounts of dust. This seasonal cycle is consistent with observations of dust plumes from MODIS and TOMS AOT climatology (Washington and Todd, 2005). It should be noted that the contribution of Bodélé dust transported south-westward over the Sahel is particularly strong in the northern hemisphere winter months, at the same time when widespread biomass burning occurs in the savannah regions. Thus, mixtures of dust particles and biomass smoke in this region may actually contain a considerable amount of diatomite particles, which can have considerably different surface properties compared to quartz/clay aggregates. Over most of the North Atlantic Ocean, where highest dust concentrations are found, dust from the more western regions of the Sahara like Mauritania dominate over the contribution from Bodélé dust. For 

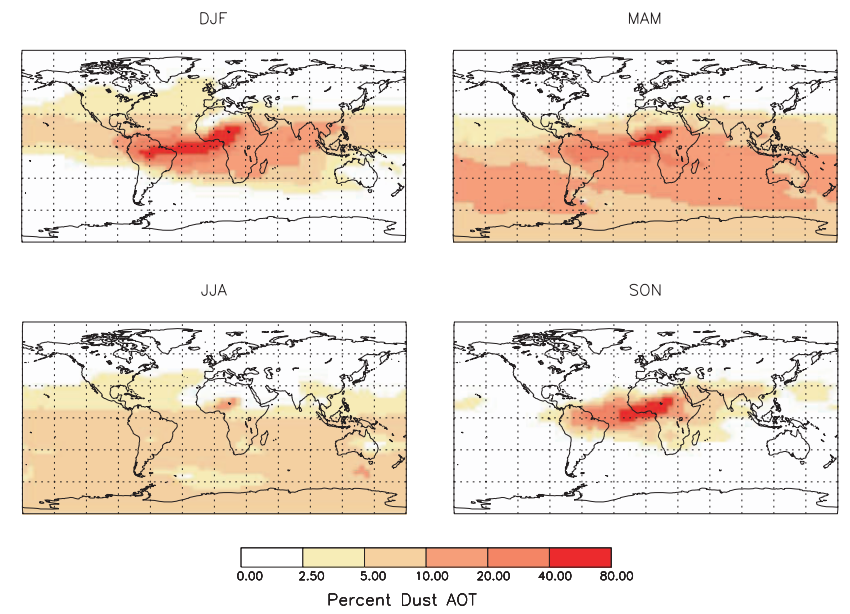

Fig. 12. Percent contribution of the Bodélé dust optical thickness to total DOT for the different seasons.

example, at the Cape Verde Islands, where aerosol optical thickness is measured continuously as part of the AERONET network, the model results indicate that contribution of dust from the Bodélé is usually lower than 10-20\% depending on the season. These results may be model-dependent and the impact of the emission scheme or type reanalysis winds used for this study should be further investigated.

\section{Discussion and conclusions}

We used a dust emission model combined with different transport models to interpret the first results from the BoDEx field experiment from March 2005. While uncertainties in the parameterization of input parameters of the dust emission model remain for this region, we summarize our findings as follows:

1. Emissions from the diatomite deposits in the Bodélé depression computed with the emission model by Marticorena and Bergametti (1995) result in dust aerosol optical thicknesses and size distributions that are consistent with the retrievals by sunphotometers during the BoDEx campaign in particular when using the observed surface wind speeds at the field site to compute dust emission. When using surface winds extracted from the regional model LM, discrepancies between model and observations can partly be attributed to deficiencies in the surface wind speed in the Bodélé area. The size distribution of particles released by the saltation of diatomite flakes was derived considering the kinetic energy of the saltating particles similar to Alfaro et al. (1997), where the assumption of smaller binding energy of the particles by about one order of magnitude compared to the clay aggregates from that publication gave a better agreement with the observation. Ultimately it will be necessary to develop a new scheme to fully describe in a physically consistent way the process of self-abrasion of mobilized airborne diatomite flakes, which are disaggregating into fine dust particles when colliding with each other or impact onto the ground.

2. Global model results assuming that all preferential sources can be parameterized identically indicate that dust from the Bodélé depression contributes up to $40 \%$ of dust optical thickness over the tropical Atlantic, and higher than $50 \%$ in the Sahel region in the northern hemisphere winter months, when mixing with biomass smoke can be expected. In addition, dust from the Bodélé may play an important role for fertilizing the Amazon rain forest. The contribution of the Bodele dust to the optical thickness of the northern Atlantic dust is small.

3. Diatomite deposits are highly reflective at solar wavelengths resulting in high single scattering albedo of dust from this area (Todd et al., 2006). However, these optical properties are not necessarily representative for dust from other regions of the Sahara that may have higher content of iron oxides and clay minerals, and dominate large parts of dust optical thickness over North Africa and the North Atlantic Ocean outside of the tropics. The extent to which the magnitude of this contribution depends on the global model itself needs to be explored.

4. The Bodélé dust event could be reasonable well reproduced by the regional model, although peak wind speeds were lower than the measurements even with the high spatial resolution of $7 \mathrm{~km}$. More attention will have to be given to turbulent mixing in the boundary layer in the regional model. Model results show that during the dust storm dust causes a daytime temperature reduction of about $5 \mathrm{~K}$ between 8 March before, and 10 March after the start of the dust storm. This accounts for about half of the temperature decrease measured in the field during this time period. This radiative effect of the dust aerosol is stabilizing the lower atmosphere during daytime, and feedback on dust production itself will be further investigated in a forthcoming publication.

Dust from the Bodélé, which probably has a large contribution of diatomite particles, may have quite different surface properties compared to dust observed in e.g. the northern $\mathrm{Sa}$ hara, which is mostly described by a mixture of clay aggregates. It may have different radiative properties, and have different effects on atmospheric chemistry and cloud formation compared to the usual clay and quartz compounds. The results clearly indicate that dust aerosol has a considerable impact on meteorological parameters like surface temperatue near source regions, which however is likely to depend on its optical properties like its complex refractive index, which 
would be regionally variable. To quantify the radiative impact of dust on meteorology and ultimately improve weather forecast parameters, further studies investigating the role of dust optical properties are required. The role of dust from the Bodélé and the different properties compared to North Saharan dust should be further clarified in upcoming field experiments with focus on Saharan dust, like the SAMUM field experiment which will take place in 2006 in Morocco.

Acknowledgements. The research was partly supported by the DFG (German Science Foundation) in the framework of SAMUM. The Royal Geographical Society Gilchrist Educational trust provided funding for the field campaign. A. Wilson of the Centre for Ecology and Hydrology, UK kindly supplied the Cimel instrument for this project; NERC EPFS and NASA GSFC are acknowledged for providing the Microtops instruments. We thank R. Wolke for help with the model development.

Edited by: U. Lohmann

\section{References}

Alfaro, S., Gaudichet, A., Gomes, L., and Maillé, M.: Modeling the size distribution of a soil aerosol produced by sandblasting, J. Geophys. Res., 102, 11 239-11 249, 1997.

Ansmann, A., Mattis, I., Müller, D., Wandinger, U., Radlach, M., Althausen, D., and Damoah, R.: Ice formation in Saharan dust over central Europe observed with temperature/humidity/aerosol Raman lidar, J. Geophys. Res., 110, D18S12, doi:10.1029/2004JD005000, 2005.

Bonasoni, P., Cristofanelli, P., Calzolari, F., Bonafe, U., Evangelisti, F., Stohl, A., Sajani, S. Z., van Dingenen, R., Colombo, T., and Balkanski, Y.: Aerosol-ozone correlations during dust transport episodes, Atmos. Chem. Phys., 4, 1201-1215, 2004 ,

http://www.atmos-chem-phys.net/4/1201/2004/.

Cakmur, R. V., Miller, R. L., and Torres, O.: Incorporating the effect of small scale circulations upon dust emission in an AGCM, J. Geophys. Res., 109, D07201, doi:10.1029/2003JD004067, 2004.

Cakmur, R. V., Miller, R. L., Perlwitz, J., Geogdzhayev, I. V., Ginoux, P., Koch, D., Kohfeld, K. E., Tegen, I., and Zender C. S.: Constraining the global dust emission and load by minimizing the difference between the model and observations, J. Geophys. Res., 111, D06207, doi:10.1029/2005JD005791, 2006.

Chadwick, L. A., Derry, O. A., Vitousek, P. M., Huebert, B. J., and Hedin, L. O.: Changing sources of nutrients during four million years of ecosystem development, Nature, 397, 491-497, 1999.

Coe, M. T.: A linked global model of terrestrial hydrologic processes: Simulation of modern rivers, lakes, and wetlands, J. Geophys. Res., 103, 8885-8899, 1998.

Damnati, B.: Holocene lake records in the Northern Hemisphere of Africa, J. African Earth Sci., 31(2), 253-262, 2000.

Dentener, F. J., Carmichael, G. R., Zhang, Y., Lelieveld, J., and Crutzen, P. J.: Role of mineral aerosol as reactive surface in the global troposphere, J. Geophys. Res., 101, 22 869-22 889, 1996.

Doms, G. and Schättler, U.: The nonhydrostatic limited area model LM (Lokal Modell) of DWD: Part1: Scientific Documentation, DWD, GB Forschung und Entwicklung, 1999.
Dubovik, O. and King, M. D.: A flexible algorithm for retrieval of aerosol optical properties from sun and sky radiance measurements, J. Geophys. Res., 105, 20 673-20 696, 2000.

Dubovik, O., Holben, B. N., Eck, T. F., Smirnov, A., Kaufman, Y. J., King, M. D., Tanré, D., and Slutsker, I.: Variability of absorption and optical properties of key aerosol types observed in worldwide locations, J. Atmos. Sci., 59, 590-608, 2002a.

Dubovik, O., Holben, B. N., Lapyonok, T., Sinyuk, A., Mishchenko, M. I., Yang, P., and Slutsker, I.: Non-spherical aerosol retrieval method employing light scattering by spheriods, Geophys. Res. Lett., 29, 54-1-54-4, 2002b.

Dubovik, O., Sinyuk, A., Lapyonok, T., Holben, B. N., Mishchenko, M., Yang, P., Eck, T. F., Volten, H., Munoz, O., Veihelmann, B., van der Zande, W. J., Leon, J.-F., Sorokin, M., and Slutsker, I.: The application of spheroid models to account for aerosol particle non-sphericity in remote sensing of desert dust, J. Geophys. Res., 111, D11208, doi:10.1029/2005JD006619, 2006.

Engelstaedter, S., Kohfeld, K. E., Tegen, I., and Harrison, S. P.: Controls of dust emissions by vegetation and topographic depressions: An evaluation using dust storm frequency data, Geophys. Res. Lett., 30(6), 1294, doi:10.1029/2002GL016471, 2003.

Giles, J.: The dustiest place on Earth, Nature, 434, 816-819, 2005.

Gillette, D.: A wind tunnel simulation of the erosion of soil: Effect of soil texture, sandblasting, wind speed, and soil consolidation on dust production, Atmos. Environ., 12, 1735-1743, 1978.

Ginoux, P., Chin, M., Tegen, I., Prospero, J., Holben B., Dubovik O., and Lin, S.-J.: Global simulation of dust in the troposphere: Model description and assessment, J. Geophys. Res., 106, 20 255-20273, 2001.

Goudie, A. and Middleton, N.: Saharan dust storms: Nature and consequences, Earth-Sci. Rev., 56, 179-204, 2001.

Grini, A., Myhre, G., Zender, C. S., and Isaksen, I. S.: Model simulations of dust sources and transport in the global atmosphere: Effects of soil erodibility and wind speed variability, J. Geophys. Res., 110, D02205, doi:10.1029/2004JD005037, 2005.

Haywood, J. M., Francis, P., Osborne, S., Glew, M., Loeb, N., Highwood, E., Tanré, D., Myhre, G., Formenti, P., and Hirst, R.: Radiative properties and direct radiative effect of Saharan dust measured by the C-130 aircraft during SHADE: 1 . Solar spectrum, J. Geophys. Res., 108, 8577, doi:10.1029/2002JD002687, 2003.

Haywood, J. M., Allan, R. P., Culverwell, I., Slingo, T., Milton, S., and Edwards, J.: Can desert dust explain the outgoing longwave radiation anomaly over the Sahara during July 2003?, J. Geophys. Res., 110, D05105, doi:10.1029/2004jd005232, 2005.

Herman, J. R., Bhartia, P. K., Torres, O., Hsu, C., Seftor, C., and Celarier, E.: Global distribution of UV-absorbing aerosols from Nimbus 7/TOMS data, J. Geophys. Res., 102, 16911-16922, 1997.

Holben, B. N., Eck, T. F., Slutsker, I., Tanre, D., Buis, J. P., Setzer, A., Vermote, E., Reagan, J. A., Kaufman, Y., Nakajima, T., Lavenu, F., Jankowiak, I., and Smirnov, A.: AERONET - A federated instrument network and data archive for aerosol characterization, Rem. Sens. Environ., 66, 1-16, 1998.

IPCC (Intergovernmental Panel on Climate Change): Radiative forcing of climate change, in: Climate Change 2001, Cambridge Univ. Press, New York, Cambridge University Press, 2001.

Jickells, T. D, An, Z. S., Andersen, K. K., Baker, A. R., Bergametti, G., Brooks, N., Cao, J. J., Boyd, P. W., Duce, R. A., Hunter, K. A., Kawahata, H., Kubilay, N., LaRoche, J., Liss, P. S., Ma- 
howald, N. M., Prospero, J. M., Ridgwell, A. J., Tegen, I., and Torres, R.: Global iron connections between desert dust, ocean biogeochemistry, and climate, Science, 308, 67-71, 2005.

Knoth, O. and Wolke, R.: An explicit-implicit numerical approach for atmospheric chemistry-transport modelling, Atmos. Environ., 32, 1785-1797, 1998.

Lacis, A. A. and Mishchenko, M. I.: Climate forcing, climate sensitivity, and climate response: A radiative modeling persepctive on atmospheric aerosols, in: Aerosol Forcing of Climate: Report of the Dahlem Workshop on Aerosol Forcing of Climate, Berlin 1994, April 24-29, edited by: Charlson, R. J. and Heintzenberg, J., John Wiley Sons, Chichester, England/New York, 1995.

Lu, H. and Shao, Y.: A new dust model for dust emission by saltation bombardment, J. Geophys. Res., 104, 16 827-16 841, 1999.

Lunt, D. J. and Valdes, P. J.: The modern dust cycle: Comparison of model results with observations and study of sensitivities, J. Geophys. Res., 107, 4669, doi:10.1029/2002JD00231, 2002.

Mahowald, N. M., Baker, A. R., Bergametti, G., Brooks, N., Due, R. A., Jickells, T. D., Kubilay, N., Prospero, J. M., and Tegen, I.: The atmospheric global dust cycle and iron inputs to the ocean, Global Biogeochem. Cycles, 19, GB4030, doi:10.1029/2005GB002541, 2005.

Marticorena, B. and Bergametti, G.: Modeling the atmospheric dust cycle: 1. Design of a soil-derived dust emission scheme, J. Geophys. Res., 100, 16415-16430, 1995.

Marticorena, B., Bergametti, G., Aumont, B., Callot, Y., N'Doume, C., and Legrand, M.: Modeling the atmospheric dust cycle: 2. Simulation of Saharan dust sources, J. Geophys. Res., 102, 4387-4404, 1997.

Marticorena, B., Chazette, P., Bergametti, G., Dulac, F., and Legrand, M.: Mapping the aerodynamic roughness length of desert surfaces from the POLDER/ADEOS bi-directional reflectance product, Int. J. Rem. Sens., 25, 603-626, 2004.

Martin, J. H.: Glacial-Interglacial CO2 Change: The Iron Hypothesis, Paleoceanography, 5, 1-13, 1990.

Miller, R., Tegen, I., and Perlwitz, J.: Surface radiative forcing by soil dust aerosols and the hydrologic cycle, J. Geophys. Res., 109, D04203, doi:10.1029/2003JD004085, 2004.

Mishchenko, M. I., Travis, L. D., and Lacis, A. A.: Scattering, absorption, and emission of light by small particles, Cambridge University Press, Cambridge, UK, 2002.

Myhre, G. and Stordal, F.: Global sensitivity experiments of the radiative forcing due to mineral aerosols, J. Geophys. Res., 106, 18 193-18 204, 2001.

N'Tschayi Mbourou, G., Bertrand, J. J., and Nicholson, S. E.: The diurnal and seasonal cycles of wind-borne dust over Africa north of the equator, J. Appl. Meteorol., 36(7), 868-882, 1997.

Moody, E. G, King, M. D., Platnick, S., Schaafa, C. B., and Gao, F.: Spatially complete global spectral surface albedos: Value-added datasets derived from terra MODIS land products, IEEE Trans. Geosci. Rem. Sens., 43, 144-158, 2005.

Okin, G. S., Mahowald, N., Chadwick, O. A., and Artaxo, P.: Impact of desert dust on the biogeochemistry of phosphorus in terrestrial ecosystems, Global Biogeochem. Cycles, 18, GB2005, doi:10.1029/2003GB002145, 2004.

Perlwitz, J., Tegen, I., and Miller, R.: Interactive soil dust aerosol model in the GISS GCM. Part I: Sensitivity of the soil dust cycle to radiative properties of dust aerosols, J. Geophys. Res., 106, 18 167-18 192, 2001.
Prigent, C., Tegen, I., Aires, F., Marticorena, B., and Zribi, M.: Estimation of the aerodynamic roughness length in arid and semiarid regions over the globe with the ERS scatterometer, J. Geophys. Res., 110, D09205, doi:10.1029/2004JD005370, 2005.

Prospero, J. M., Ginoux, P., Torres, O., Nicholson, S. E., and Gill, T. E.: Environmental characterization of global sources of atmospheric soil dust identified with the NIMBUS 7 TOMS absorbing aerosol product, Rev. Geophys., 40, 1002, doi:10.1029/2000RG000095, 2002.

Prospero, J. M. and Lamb, P. J.: African droughts and dust transport to the Caribbean: Climate change implications, Science, 302, 1024-1027, 2003.

Schuster, M., Roquin, C., Duringer, P., Brunet, M., Caugy, M., Fontugne, M., Mackaye, H. T., Vignaud, P., and Ghienne, J. F.: Holocene Lake Mega-Chad palaeoshorelines from space, Quatern. Sci. Rev., 24, 1821-1827, 2005.

Seinfeld, J. H. and Pandis, S. N.: Atmospheric Chemistry and Physics: From Air Pollution to Climate Change, John Wiley, New York, 1997.

Stier, P., Feichter, J., Kinne, S., Kloster, S., Vignati, E., Wilson, J. D., Ganzeveld, L., Tegen, I., Werner, M., Balkanski, Y., Schulz, M., Boucher, O., Minikin, A., and Petzold, A.: The aerosolclimate model ECHAM5-HAM, Atmos. Chem. Phys., 5, 11251156, 2005, http://www.atmos-chem-phys.net/5/1125/2005/.

Tegen, I., Harrison, S. P., Kohfeld, K. E., Prentice, I. C., Coe, M. C., and Heimann, M.: Impact of vegetation and preferential source areas on global dust aerosol: Results from a model study, J. Geophys. Res., 107, 4576, doi:10.1029/2001JD000963, 2002.

Tegen, I., Werner, M., Harrison, S. P., and Kohfeld, K. E.: Relative importance of climate and land use in determining present and future global soil dust emission, Geophys. Res. Lett., 31, L05105, doi:10.1029/2003GL019216, 2004.

Todd, M. C., Washington, R., Martins, V., Lizcano, G., Dubovik, O., M'Bainayel, S., and Engelstaedter, S.: Properties of mineral dust from the Bodélé depression, Northern Chad during BodEx 2005, J. Geophys. Res., in press, 2006.

Tucker, C. J., Pinzon, J. E., Brown, M. E., Slayback, D. A., Pak, E. W., Mahoney, R., Vermote, E. F., and El Saleous, N.: An extended AVHRR 8-km NDVI dataset compatible with MODIS and SPOT vegetation NDVI data, Int. J. Rem. Sens., 26, 44854498, 2005.

Volten, H., Munoz, O., Rol, E., de Haan, J. F., Vassen, W., Hovenier, J. W., Muinonen, K., and Nousiainen, T.: Scattering matrices of mineral aerosol particles at $441.6 \mathrm{~nm}$ and $632.8 \mathrm{~nm}$, J. Geophys. Res., 106, 17 375-17 401, 2001.

Volz, F. E.: Infrared Optical Constants of Ammonium Sulfate, Sahara Dust, Volcanic Pumice, and Flyash, Appl. Opt., 12, 564568, 1973.

Washington, R. W., Todd, M. C., Middleton, N., and Goudie, A. S.: Dust-storm source areas determined by the total ozone monitoring spectrometer and surface observations, Ann. Assoc. Am. Geogr., 93, 297-313, 2003.

Washington, R. and Todd, M. C.: Atmospheric controls on mineral dust emission from the Bodele Depression, Chad: The role of the low level jet, Geophys. Res. Lett., 32, L17701, doi:10.1029/2005GL023597, 2005.

Washington, R., Todd, M. C., Engelstaedter, S., M'bainayel, S., and Mitchell, F.: Dust and the Low Level Circulation over the Bodélé 
Depression, Chad: Observations from BoDEx 2005, J. Geophys. Res., 111, D03201, doi:10.1029/2005JD006502, 2006.

Wolke, R. and Knoth, O.: Implicit-explicit Runge-Kutta methods applied to atmospheric chemistry-transport modelling, Env. Mod. and Software, 15, 711-719, 2000.

Wurzler, S., Reisin, T. G., and Levin, Z.: Modification of mineral dust particles by cloud processing and subsequent effects on drop size distributions, J. Geophys. Res., 105, 4501-4512, 2000.
Zender, C., Newman, D., and Torres, O.: Spatial Heterogeneity in aerolian erodibility: Uniform, topographic, geomorphic, and hydrologic hypotheses, J. Geophys. Res., 108(D17), 4543, doi:10.1029/2002JD003039, 2003.

Zobler, L.: A world soil file for global climate modeling, Tech. Rep. NASA TM-87802, 32 pp., NASA, Washington, D.C., 1986. 